Nat. Hazards Earth Syst. Sci., 17, 1493-1503, 2017

https://doi.org/10.5194/nhess-17-1493-2017

(C) Author(s) 2017. This work is distributed under

the Creative Commons Attribution 3.0 License.

\title{
Rip current evidence by hydrodynamic simulations, bathymetric surveys and UAV observation
}

\author{
Guido Benassai ${ }^{1}$, Pietro Aucelli ${ }^{2}$, Giorgio Budillon ${ }^{2}$, Massimo De Stefano ${ }^{2}$, Diana Di Luccio ${ }^{2}$, Gianluigi Di Paola $^{2}$, \\ Raffaele Montella ${ }^{2}$, Luigi Mucerino ${ }^{3}$, Mario Sica ${ }^{4}$, and Micla Pennetta ${ }^{5}$ \\ ${ }^{1}$ Department of Engineering, Parthenope University of Naples, 80133, Naples, Italy \\ ${ }^{2}$ Department of Science and Technology, Parthenope University of Naples, 80133, Naples, Italy \\ ${ }^{3}$ Department of Earth, Environment and Life Sciences, University of Genova, 16126, Genova, Italy \\ ${ }^{4}$ Autorità di Bacino Campania Centrale, 80138, Naples, Italy \\ ${ }^{5}$ Department of Earth, Environment and Resources Sciences, University of Naples Federico II, 80138, Naples, Italy \\ Correspondence to: Guido Benassai (guido.benassai@uniparthenope.it)
}

Received: 31 January 2017 - Discussion started: 3 March 2017

Revised: 27 July 2017 - Accepted: 30 July 2017 - Published: 12 September 2017

\begin{abstract}
The prediction of the formation, spacing and location of rip currents is a scientific challenge that can be achieved by means of different complementary methods. In this paper the analysis of numerical and experimental data, including RPAS (remotely piloted aircraft systems) observations, allowed us to detect the presence of rip currents and rip channels at the mouth of Sele River, in the Gulf of Salerno, southern Italy. The dataset used to analyze these phenomena consisted of two different bathymetric surveys, a detailed sediment analysis and a set of high-resolution wave numerical simulations, completed with Google Earth ${ }^{\mathrm{TM}}$ images and RPAS observations. The grain size trend analysis and the numerical simulations allowed us to identify the rip current occurrence, forced by topographically constrained channels incised on the seabed, which were compared with observations.
\end{abstract}

\section{Introduction}

The monitoring and the forecasting of beach processes become particularly critical along the unstable coastal areas, possibly subjected to coastal vulnerability (Di Paola et al., 2014), and coastal risk due to sea level rise (Benassai et al., 2015) and subsidence (Aucelli et al., 2017). The evolution of winds, waves and wind-driven sea circulation is of great applicative relevance for the observation of oceanographic phenomena (Bidlot et al., 2002). The offshore wind-wave simulations are accomplished by observations obtained by satel- lite images by active satellite-based microwave Synthetic Aperture Radar (SAR) (Benassai et al., 2012b, a, 2013), while the coastline monitoring can be surveyed by remote sensing acquisition (Nunziata et al., 2016, 2014) or, on a shorter timescale, by RPAS (remotely piloted aircraft systems) and video monitoring systems (Casella et al., 2014). A possible feedback between wave-driven circulation, sediment processes and beach morphology is the occurrence of rip currents.

Rip currents are narrow, intense seaward-flowing jets that originate within the surf zone and broaden outside the breaking zone. The alongshore variation of wave height fuels modification of wave-induced momentum flux or radiation stress (Longuet-Higgins and Stewart, 1964), the cross-shore gradient of which is balanced by the hydrostatic pressure, giving rise to wave setup on the beach. The longitudinal gradient of setup generates local long-shore currents that concentrate and join up to generate an offshore return flow that forms the rip current. This gradient can be caused by alongshore differences of incident wave fields due to wave groups (Dalrymple, 1975), wave-current interactions (Dalrymple and Lozano, 1978) or wave field interaction with edge waves (Symonds and Ranasinghe, 2001).

Comprehensive rip current observations require bathymetry measurements, directional wave records, tide and current detection. Alternatively, wave climate can be simulated with high-resolution numerical models in order to obtain the rip current spacing, which is comparable with 
their wavelength. With regard to bathymetry, rip channels have found to be quasi-periodic alongshore perturbations which occur at the observed alongshore spacing $\mathrm{O}(100 \mathrm{~m})$ (MacMahan et al., 2006), when the waves approach at near-normal incidence (Bowen, 1969).

With regard to tides, rip currents have long been observed to vary within the tide elevation; in particular they are tidally modulated, such that a decrease in tidal elevation leads to an increase of rip current flow to a relative maximum (Sonu, 1972; MacMahan et al., 2005), linking the danger of rip currents to lower tidal elevations (Engle, 2002).

These strong offshore directed currents are the cause of the majority of fatalities within the beach environment (Drozdzewski et al., 2012; Brander et al., 2013; Brighton et al., 2013; Zhang et al., 2012). Therefore, many attempts have been made to relate the rip current morphology to the local wave climate, shoreline orientation, sediment size and tidal conditions. Due to a number of laboratory and field investigations, possible rip current occurrence was associated to simple parameters that can be easily evaluated with few data and field measurements. The earliest studies of rip currents paid attention to the relationship between rip current spacing and the surf zone width (Shepard and Inman, 1950). Other authors (Short and Brander, 1999; Sasaki et al., 1977) demonstrated how the rip spacing $\mathrm{y}_{\mathrm{r}}$ is directly related to the dimensionless fall velocity parameter introduced by Wright and Short (1984) to classify beach states (from dissipative to reflective):

$\Omega=\frac{H}{T w_{\mathrm{s}}}$,

where $H$ is the breaker height, $T$ is the incident wave period and $w_{\mathrm{s}}$ is the mean sediment fall velocity (Dean et al., 1973). The intermediate beach states $(\Omega=2-5)$ are characterized by rip current occurrence.

In this paper we investigated the rip current spacing and morphology with numerical and experimental methods, including RPAS observations which have been already used for topographic mapping (Turner et al., 2016), and recently extended their applicability to the surf zone characterization (Holman et al., 2017). In order to establish a correlation between beach morphology and the rip current features, the fall velocity parameter was related to rip spacing in the coastal area at the Sele River mouth in the Gulf of Salerno, which was the subject of coastal vulnerability and risk evaluation (Di Paola et al., 2011; Benassai et al., 2012a, 2014) and coastal morphodynamics (Pennetta et al., 2011b). The index $\Omega$ was constructed with the grain size diameter on different transects, together with wave conditions obtained by numerical simulations. The validation of rip current occurrence associated with the reference $\Omega$ range was supported by Google Earth $^{\mathrm{TM}}$ products (orthophoto) obtained in 2007, 2013 and 2015 and more recent images obtained by an RPAS survey. The final goal was assessing the reliability of $\Omega$ to represent an index of rip current occurrence.
These preliminary results can be used in an operational model chain contextwhich includes wind and wave forecasted characteristics in offshore conditions and their transformation in shallow water, leading to rip current prediction. In this case, the RPAS model chain validation can be crucial to detect dangerous rip current conditions associated with the $\Omega$ index.

This paper is structured as follows: the study area, with its morphological and climatological features, is introduced in Sect. 2. The data and models are described in Sect. 3. Numerical and field results are presented and discussed in Sect. 4. Discussion and conclusions are finally drawn in Sects. 5 and 6 , respectively.

\section{Study area and wave climate}

The study concerns a stretch of the beach which borders seawards the alluvial plain of the Sele River, one of the widest alluvial coastal plains of central-southern Italy. This plain stretches between the high rocky coasts of Amalfi, to the NW, and Cilento promontory to the SE (Campania) and is limited towards the sea by a narrow sandy beach which extends from NW to SE in the Gulf of Salerno, in the southern Tyrrhenian Sea (Fig. 1). The plain represents the emerged portion of a morphotectonic depression related to the opening of the Tyrrhenian ocean basin, started during the Upper Miocene (Bartole et al., 1984; Casciello et al., 2006; Aucelli et al., 2012).

The presence of beach-dune ridges, located in the outer portion of the plain, marks the sea level highstands and Upper Pleistocene paleo-coastlines. During the Holocene, three phases of sandy coastal ridges interrupted the progradational trend of the coastline, with discontinuous dune system height of about $3 \mathrm{~m}$ a.s.l. (Fig. 1a). This dune system can be considered as a natural barrier to sea ingression (e.g., Pennetta et al., 2011a; Pappone et al., 2012; Amato et al., 2013). Moreover, the back-ridge depressions, recently drained, are localized in several and large areas, with a mean elevation of 0.50/1.5 ma.s.l. (Pappone et al., 2011). During the last century, the Sele coastline was affected by erosion which was strong around the main river mouths due to numerous hydraulic dams which reduced the sediment supply. Nowadays, the coast is rather stable and only the Sele mouth zone is in erosion (Alberico et al., 2012). The wave climate was obtained by a Directional Waverider MkIII wave buoy $\left(40^{\circ} 27^{\prime} 26.4^{\prime \prime} \mathrm{N}, 14^{\circ} 51^{\prime} 41.16^{\prime \prime} \mathrm{E}\right)$ installed and managed by the Provincial Authority in the Bay of Salerno in approx. $35 \mathrm{~m}$ deep water, for the years 2014-2016. The directional distribution of the significant wave heights, consisting of 32024 samples (Fig. 1b), is in close agreement with the one obtained by the longer dataset of the offshore buoy of Ponza (Piscopia et al., 2002). Figure 1c gives the same directional distribution for significant wave heights $H_{\mathrm{s}} \geq 2 \mathrm{~m}$. Finally, the histogram in Fig. 1d shows the cumulated $H_{\mathrm{s}}$ 

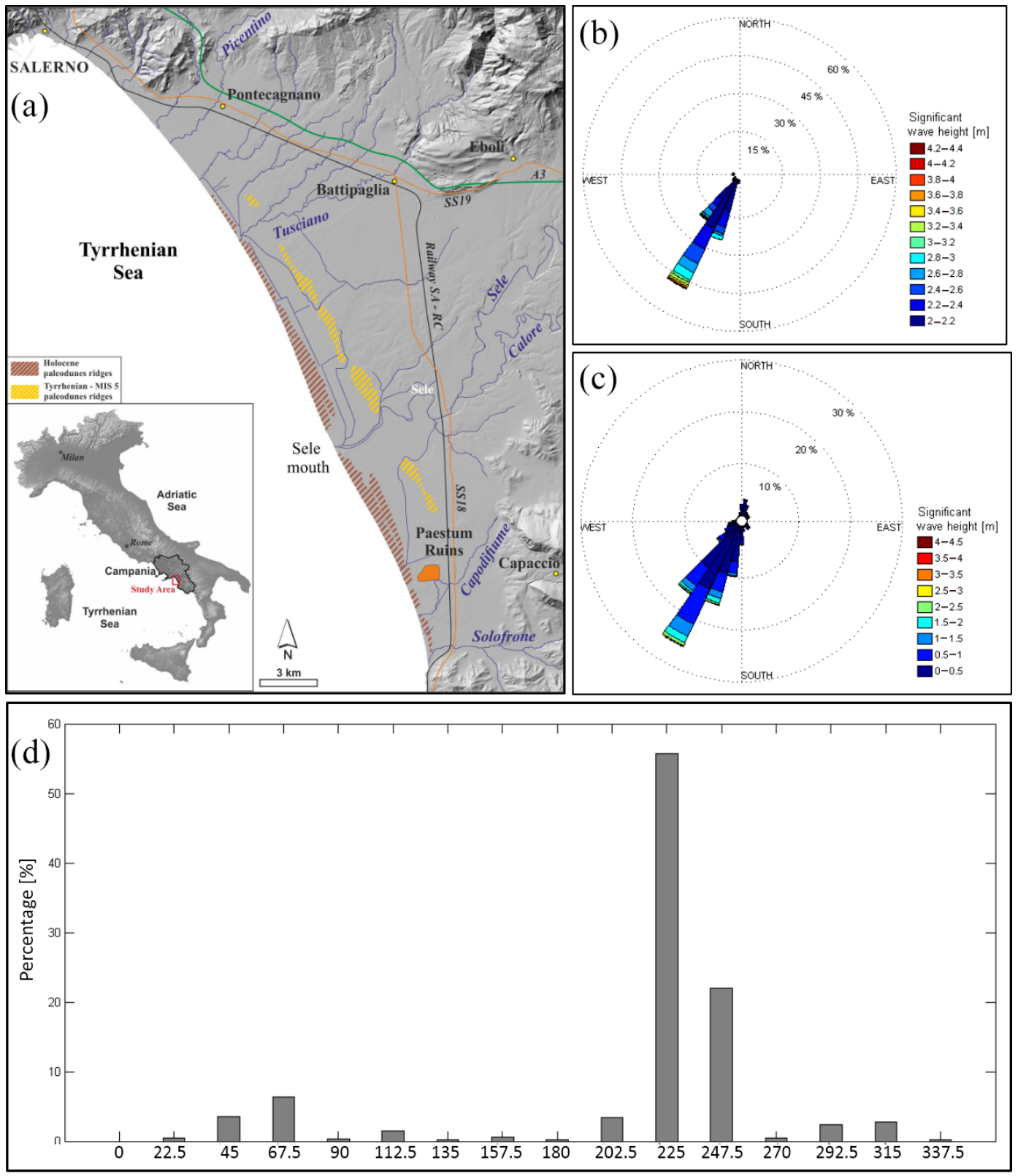

Figure 1. Location map of coastal Sele Plain (a); directional distribution of the $H_{\mathrm{S}}(\mathbf{b})$ and of the $H_{\mathrm{S}} \geq 2 \mathrm{~m}$ recorded by Salerno buoy in the 2014-2016 years (c); $H_{\mathrm{S}}$ occurrence probability $(\%)$ for each direction (d).

occurrence frequency for each direction, confirming that the wave directions associated with the most frequent waves are mainly SW (about 56\%) and WSW (about $22 \%$ ).

\section{Data and models}

\subsection{Bathymetric and sediment surveys}

In order to define a detailed mapping of emerged and submerged beach, we performed two bathymetric surveys along 155 transects spaced by $100 \mathrm{~m}$, from the dune to $10 \mathrm{~m}$ depth.
The emerged beach profile was surveyed using a Differential Global Position System (DGPS), while the submerged beach profiles were recorded using the interferometric sonar SEA SWATH plus $468 \mathrm{kHz}$ integrated with a single-beam system and a GPS RTK (Real Time Kinematic) dual-frequency navigation system. These data were included in a geographic information system (GIS) framework to generate a DTM (digital terrain model), from which the isobaths needed for detecting rip channels and bars were extracted, with a point density of $2 \mathrm{~m}$ along each transect. In order to determine the sediment mean size, during the first survey 280 sediment samples 
were collected, 120 of them in the submerged beach using a Van Veen grab sampler. The analysis of grain size distribution with the graphic method (Folk and Ward, 1957) was applied in order to relate the sediment data to morphological ones obtained in other coastal areas (De Pippo et al., 2003; Pennetta et al., 2016; Mangoni et al., 2016).

\subsection{Sediment dynamical analysis}

Submerged beach sediments grain size $(\phi)$ was collected, airdried (temperature of $105-110^{\circ} \mathrm{C}$ ) and sieved (set of silks arranged in mechanical stirrer at intervals of $1 / 2 \phi$ ) in accordance with the American Society for Testing and Materials Method D422 (ASTM D422). For each sample, we extracted the statistical parameter in accordance to Folk and Ward (1957). This statistical analysis is based on occurrence frequency identification related to the most prevalent grain size classes (mode of the grain size distribution), defined as "modal classes", of a single sediment sample. Contours of the modal isodensity were plotted by assigning the proper percentage values of the average modal formula (related to the different modal subpopulations) to sediments samples map points positions. Trend vectors were defined comparing the grain size parameters of each sample with its neighbors, identified on the basis of a characteristic distance that represents the space scale of sampling. Those vectors summarize, in terms of movement directions, the sediment dynamics on the submerged beach of the studied area.

\subsection{Wave simulation and hydrodynamic model}

In order to simulate the offshore wave features in the Gulf of Salerno and propagate them on the coastline, we used a scientific workflow (Giunta et al., 2005) implemented by the Campania Center for Marine and Atmospheric Monitoring and Modelling (CCMMMA) hosted by the Parthenope University of Naples, using a high-performance computing (HPC) system (Montella et al., 2011; Di Lauro et al., 2012) for simulation and open environmental data dissemination (Montella et al., 2007). The weather/sea forecasting tool has been configured using an HPC infrastructure to manage and run a modeling system based on the algorithms implemented in the open-source numerical models Weather Research and Forecasting (WRF) (Skamarock et al., 2001) and WaveWatchIII (WWIII) (Tolman et al., 2009), organized in a workflow (Pham et al., 2012). The operational configuration is based on the WRF numerical model, which gives the atmospheric forcing ( $10 \mathrm{~m}$ wind fields) needed to estimate the offshore waves. Wave simulations were carried out using the WWIII, a third-generation wave model developed at NOAA/NCEP. Preliminary implementation and validation for simulating the wave propagation along the Campania Region coastline (Gulf of Naples) were conducted by Benassai and Ascione (2006). Subsequently, WRF and WWIII models were coupled in an operational configuration for real- time applications, using also a high-resolution bathymetry, to simulate extreme weather coastal flooding along the coast of the municipality of Naples. The WWIII model domain has been configured with $350 \times 200$ grid points and $0.01^{\circ}$ spatial resolution in latitude $\left(\operatorname{lat}_{\min }=39.50^{\circ} \mathrm{N}\right.$, lat $\left.\mathrm{at}_{\max }=41.49^{\circ} \mathrm{N}\right)$ and in longitude $\left(\operatorname{long}_{\min }=12.50^{\circ} \mathrm{E}, \operatorname{long}_{\max }=15.99^{\circ} \mathrm{E}\right.$ ), covering the south Tyrrhenian Sea. WWIII model outputs include gridded fields with the associated significant wave heights $\left(H_{\mathrm{s}}\right)$, periods $\left(T_{\mathrm{m}}\right)$, directions (Dir) and relative spectral information.

The offshore wave model outputs were the forcing of the 2-D near-shore model XBeach (Roelvink et al., 2009). This is a 2-D model for wave propagation, long waves and mean flow, sediment transport and morphological beach changes during storms. XBeach concurrently solves the timedependent shortwave action balance, roller energy equations, nonlinear shallow water equations of mass and momentum, sediment transport formulations and the bed update on the scale of wave groups. In the Netherlands, a rip current prediction model system was used on the basis of bathymetry measurement through the application of the XBeach hydrodynamic model (Roelvink et al., 2009). In this paper, XBeach was used to confirm, through hydrodynamic simulations, the occurrence of bathymetric rips evidence by the rip channels previously identified. For this purpose, the model was run with the offshore wave conditions identified in the month of February 2008, obtained by the WWIII wave model. The computational grid was generated merging field data collected in 2008 and the deeper bathymetry, from $10 \mathrm{~m}$ to $40 \mathrm{~m}$ depth, supplied by the Istituto Idrografico della Marina Italiana. An irregular mesh was used to obtain a higher resolution across the surf zone and a lower resolution far from the coast. The size of the elements was about $5 \mathrm{~m}$ on the beach and $25 \mathrm{~m}$ off the coast. The wave conditions at the offshore boundary were inserted using the JONSWAP spectrum module using the wave condition supplied by WWIII model for rip current events highlighted by sediment transport vectors in 2008.

\subsection{RPAS survey}

Remotely piloted aerial vehicles used for scientific or research activities are defined RPAS and are subjected to the regulations of the Italian Navigation Code, in accordance with the Italian Civil Aviation Authority (ENAC) Regulation Issue no. 2 (2015). This regulation provides safety levels for different kinds of operations. The regulation classifies the RPAS according to their weight (takeoff mass lower or higher than $25 \mathrm{~kg}$ ) and classifies operations according to their criticality. In our survey, the operations are defined as VLOS (visual line of sight) because the remote pilot maintains continuous visual contact with the aerial vehicle. VLOS operations are permitted in daylight, up to a maximum height of $150 \mathrm{~m}$ above ground level, within a maximum horizontal distance of $500 \mathrm{~m}$. Our beach survey was defined "non-critical" because 

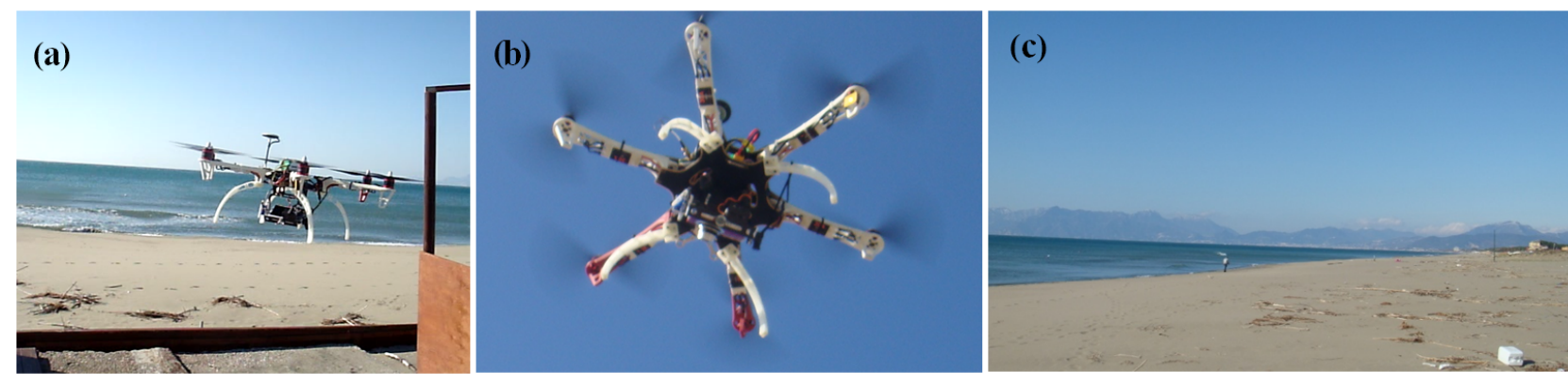

Figure 2. RPAS on flight on the surveyed beach.

Table 1. Frequency distribution for each modal class of the sample.

\begin{tabular}{llrrr}
\hline & Modal class & Size range $(\mathrm{mm})$ & Modal peak $(\mathrm{mm})$ & Frequency $(\%)$ \\
\hline SP1 & Gravel & $19.214-2.378$ & 2.378 & 2.06 \\
SP2 & Coarse sand & $0.802-0.595$ & 0.595 & 21.76 \\
SP3 & Medium sand & $0.296-0.254$ & 0.294 & 25.45 \\
SP4 & Fine sand & $0.250-0.210$ & 0.213 & 20.08 \\
SP5 & Very fine sand & $0.105-0.101$ & 0.102 & 30.66 \\
\hline
\end{tabular}

it consisted of VLOS operations which do not fly over, even in case of malfunction and/or failures, (i) congested areas, gathering of persons, urban areas or (ii) critical infrastructures.

In order to perform rip current observations (Fig. 2a, b, c) we used an RPAS hexacopter which weighed about $2500 \mathrm{~g}$, carrying a GPS, a multi-directional accelerometer and a remote flight control. The max height and max radius (vertical and horizontal distance between the aircraft and the home point) were set to the default value of $2000 \mathrm{~m}$. The hovering accuracy was $\pm 0.8 \mathrm{~m}$ in vertical and $\pm 2.5 \mathrm{~m}$ in horizontal, while the max ascent and descent speeds were 6 and $4.5 \mathrm{~m} \mathrm{~s}^{-1}$, respectively. A failsafe function system was activated if the connection between the multirotor and the remote control was accidentally disconnected during flight, which provided recovery to the point of takeoff and land automatically. The RPAS was equipped with a Canon ELPH 130 camera with 16 megapixel (4608 by 3456 pixels) sensor because of its lightweight, manual functions and programming capabilities through open-source custom software.

In order to generate orthophotos from the acquired RPAS photos, we used the Z-Map software produced by MENCI, allowing us to correct and eliminate radial distortion, relief distortion, tilt and pitch of aircraft and scale variations caused by changes in altitude along the flight lines. Therefore, by means of this methodology an orthophoto of the area has been obtained with a root-mean-square error of $\pm 1 \mathrm{~m}$. The orthorectified aerial images has been georeferenced using ground control points measured at the ground altitude using the Trimble R6 DGPS in RTK mode, a differential GNSS technique which provides high positioning performance in the proximity of a base station (FISC-35; lat $=40^{\circ} 46^{\prime} 13.74^{\prime \prime}$, long $=14^{\circ} 47^{\prime} 24.91^{\prime \prime}$; http://it.smartnet-eu.com). As target points for DGPS we used some fixed structures and 25 mobile targets (rectangular red card, $297-240 \mathrm{~mm}$ ) placed on the berm terrace for the time of the survey.

\section{Results}

\subsection{Sediment analysis and morphodynamics}

A comparison of different profiles was used to make morphodynamic characterization on the study area. The bathymetric difference between the DTM recorded in February and September 2008 was mapped with a resolution of $5 \times 5 \mathrm{~m}^{2}$, with the areas suffering from a bathymetric drop of more than $0.1 \mathrm{~m}$ (reduction of sediment volumes), the ones characterized by a bathymetric lifting of more than $0.1 \mathrm{~m}$ (increased sediment volumes) and the areas remaining substantially in equilibrium, with the difference in height between -0.1 and $+0.1 \mathrm{~m}$ (Fig. 3a, with the detail north of the Sele mouth in Fig. 3b).

The comparison between the two morphological structures derived from the different bathymetric surveys show the formation of transverse channels to the coast, engraved at the bottom, probably generated by rip currents. These channels are developed mainly between 0 and $5 \mathrm{~m}$ affecting the bars, in origin parallel to the shore, fragmenting them into smaller sand bars, transverse to the shoreline. The bars are constituted by fine and relatively unsorted sands. The increased size of the sediment in the channels as well as its higher 
Table 2. Wave characteristics during numerical simulations and remote observations.

\begin{tabular}{lrrrrr}
\hline & $28 / 06 / 2007$ & $02 / 02 / 2008$ & $02 / 05 / 2013$ & $29 / 05 / 2015$ & $21 / 01 / 2017$ \\
\hline$H_{\mathrm{S}}(\mathrm{m})$ & 1.46 & 0.91 & 0.33 & 0.46 & 0.67 \\
\hline$T_{\mathrm{m}}(\mathrm{s})$ & 5.8 & 4.11 & 2.99 & 3.47 & 2.71 \\
\hline $\operatorname{Dir}\left({ }^{\circ} \mathrm{N}\right)$ & 275.10 & 228.29 & 284.23 & 206.20 & 14.83 \\
\hline
\end{tabular}

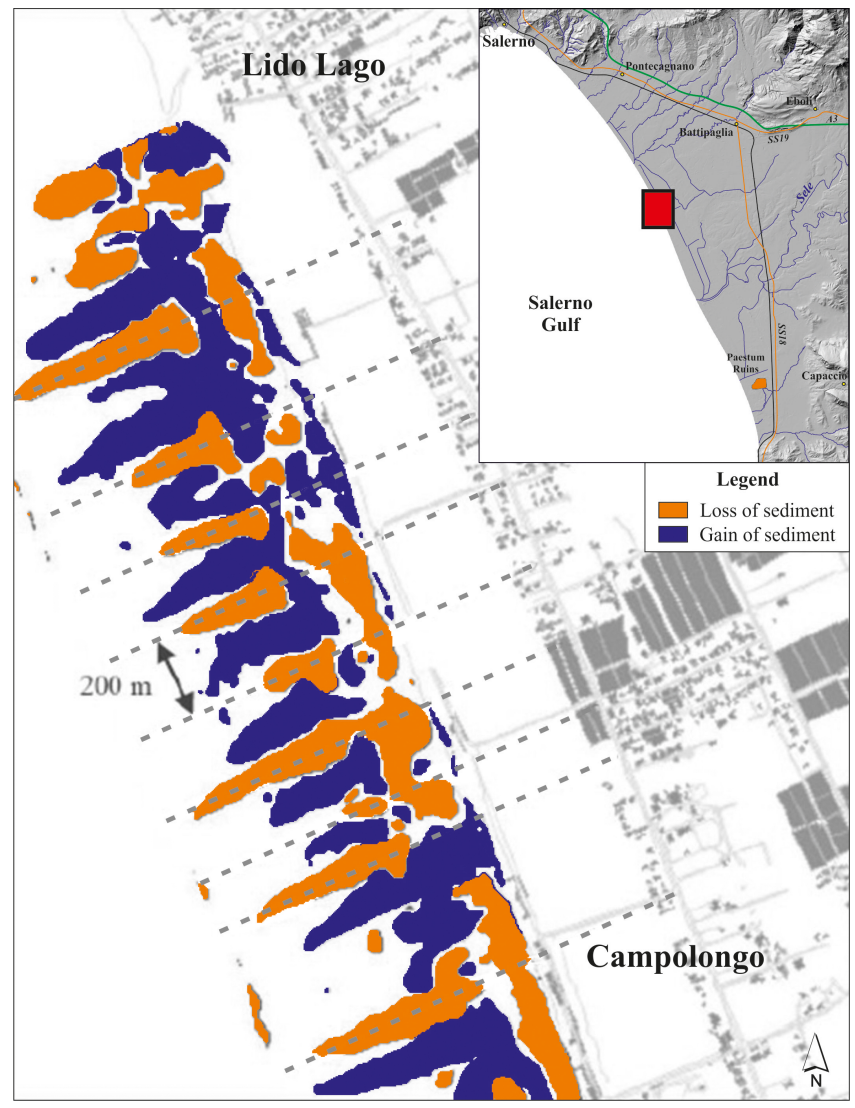

Figure 3. Loss and gain of sediment volumes in the north of the Sele mouth (modified from Pennetta et al., 2011b). The dotted lines represent the rip channels identifying the most probable position of the rip currents.

sorting correlates well with the high hydrodynamic energy of flowing water in the channels modeled by rip currents.

\subsection{Hydrodynamics}

The results of the offshore wave numerical simulations and propagation on shoaling waters have been used to establish the inshore wave conditions which are responsible for the sediment transport behavior. In particular, the waves coming offshore from WSW, which occur with almost $20 \%$ percentage due to a significant clockwise rotation in the shoaling zone, gave rise to waves almost normal to the bathymetry.
The wave normal incidence is responsible for the coastal cell circulation and the associated rip currents (Fig. 4a).

The waves coming offshore from SW, which occur with almost $58 \%$ also show a similar behavior, giving rise to the same cell circulation. Nevertheless, the frequency distributions of the highest waves show the more significant influence of the western waves, which are susceptible to generate an almost long-shore transport coming from NW.

The XBeach model output reproduced the rip currents analyzed with sediment transport vectors (Fig. 4b). The results describe the wave height incidence and the flow direction simulated by XBeach model, at 16:00 of 2 February 2008. In particular, four rip current cells are evident in the simulations, as well as a significant offshore current flow through the rip spacing that is consistent with the results obtained by the morphodynamics analysis. Moreover, the results show the rotation of the flow close to the coastline during the time step considered and the decrease of the wave height in the rip neck in comparison with the feeder current zone. These results show that the rip current flows do not occur during extreme events; rather they confirm that the flows occur when the significant wave height $\left(H_{\mathrm{s}}\right)$ values are between 0.5 and $1 \mathrm{~m}$, with mean wave periods $\left(T_{\mathrm{m}}\right)$ between 4 and $6 \mathrm{~s}$. The simulations also put the emphasis on the fact that cell circulation is driven by long-shore gradients in wave setup and beach morphology.

\subsection{Transport trends}

The procedure proposed by Gao and Collins (1994) defined trend vectors for the 120 sampling considered. According to this procedure, five grain size trends were associated with net transport directions, reported in Table 1 together with their percentage of occurrence. Coarse sand (SP2) with a frequency of $21.76 \%$, medium sand (SP3) with a frequency of occurrence of $25.45 \%$, fine sand (SP4) with a frequency of occurrence $20.08 \%$ and very fine sand (SP5) with a frequency of occurrence of $30.66 \%$ were the most statistically significant classes for the sediment transport vectors identification. The first was allocated more or less in a uniform way, between foreshore and the depth of $-2 \mathrm{~m}$, while the second showed a spot pattern between foreshore and the depth of $-3 \mathrm{~m}$. The third is confined to a wide zone of the submerged beach, and the last one is located all over the submerged beach with a modal frequency gradient follow- 


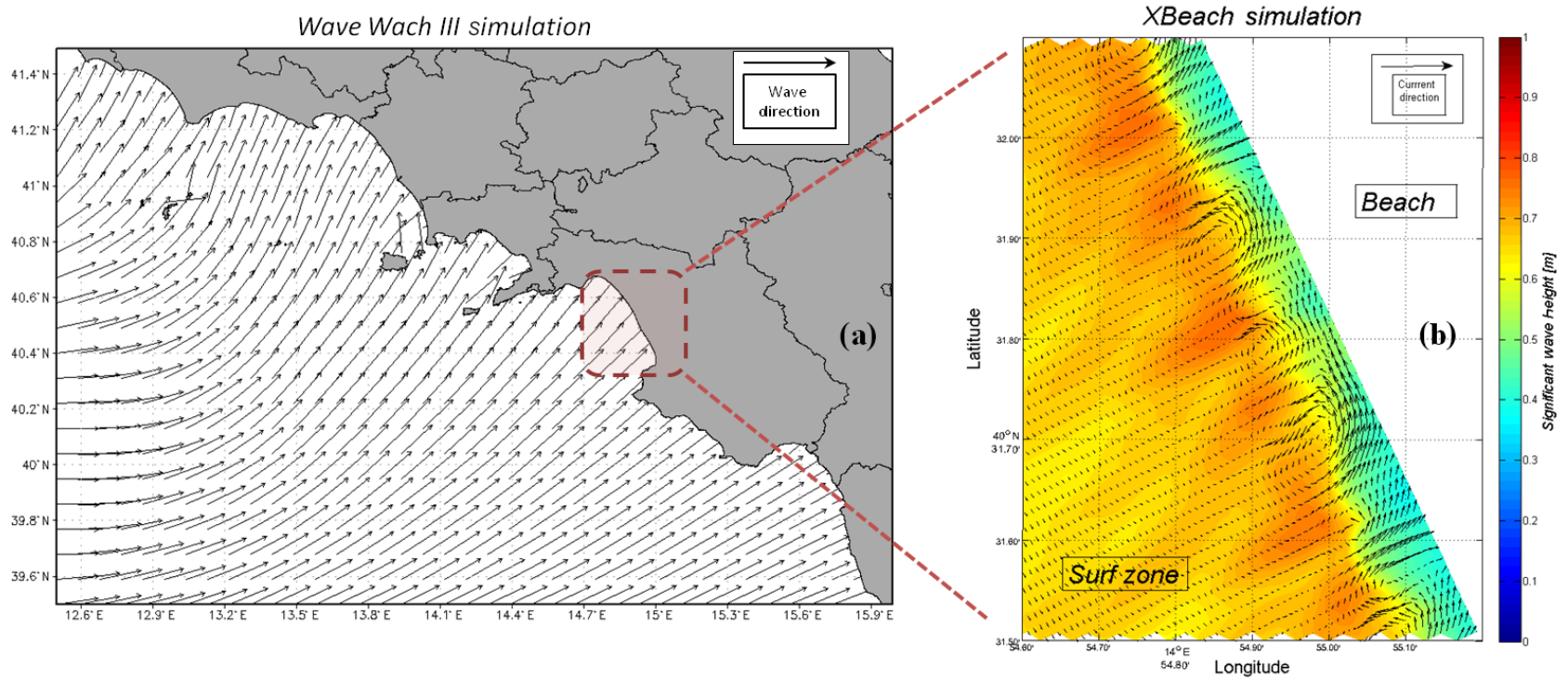

Figure 4. Offshore wave simulation associated with bathymetric survey of February 2008 with wave direction coming from WSW (a). Hydrodynamic wave simulation giving rise to rip current formation (b).
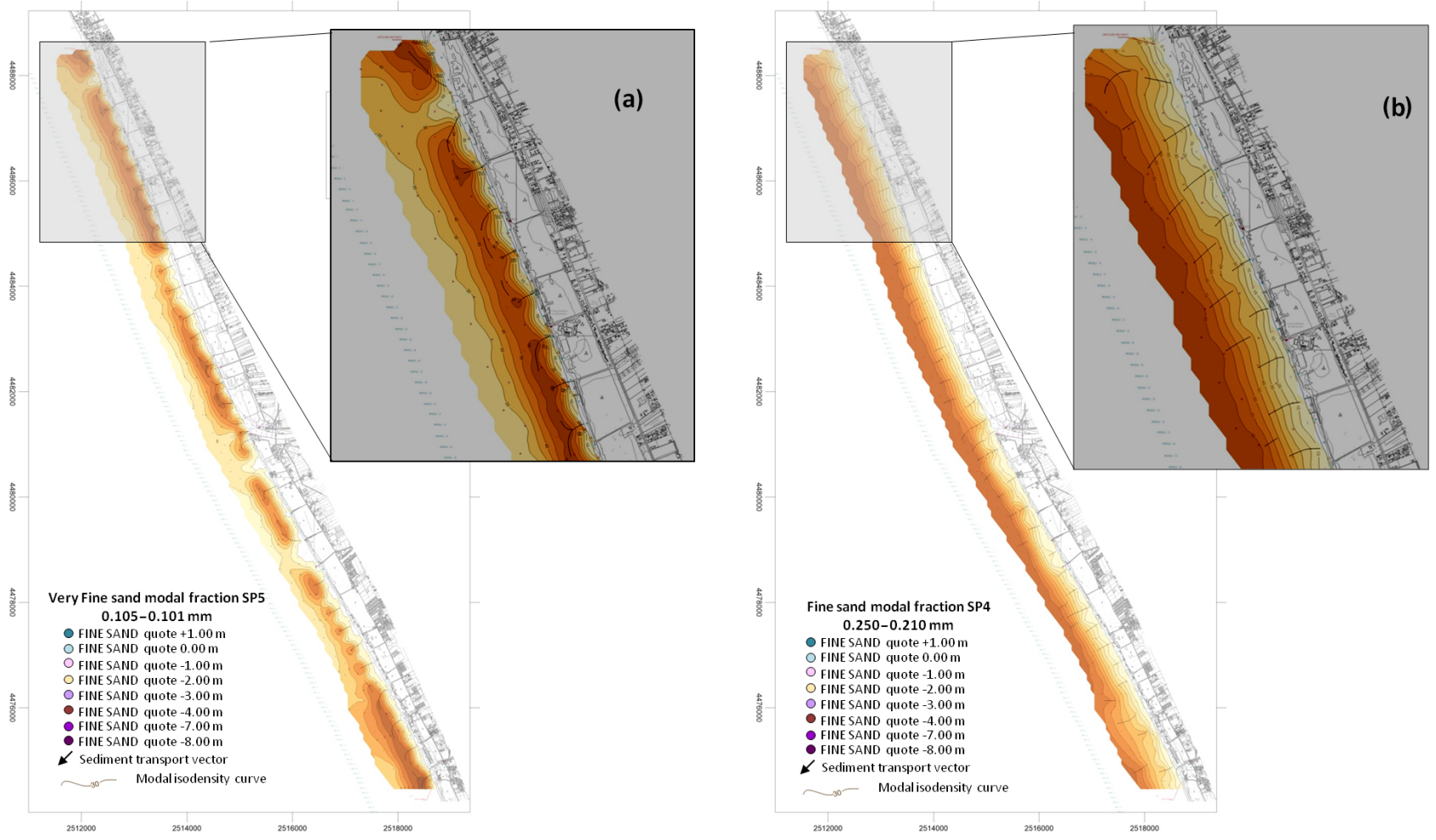

Figure 5. Sediment transport vectors for the whole area referred to the modal subpopulation SP5 - very fine sand (a) - and SP4 - fine sand (b).

ing the bathymetry patterns towards the open sea (according to the typical behavior of the lower grain size particles). This very fine sand modal fraction SP5 was mostly associated with the rip currents, evidenced by well-defined sedi- ment transport vectors patterns, with moving directions (perpendicular to the shoreline) towards the open sea (Fig. 5a). The modal subpopulation SP4 (fine sand) showed a more complex coastal dynamics (Fig. 5b). This grain size frac- 

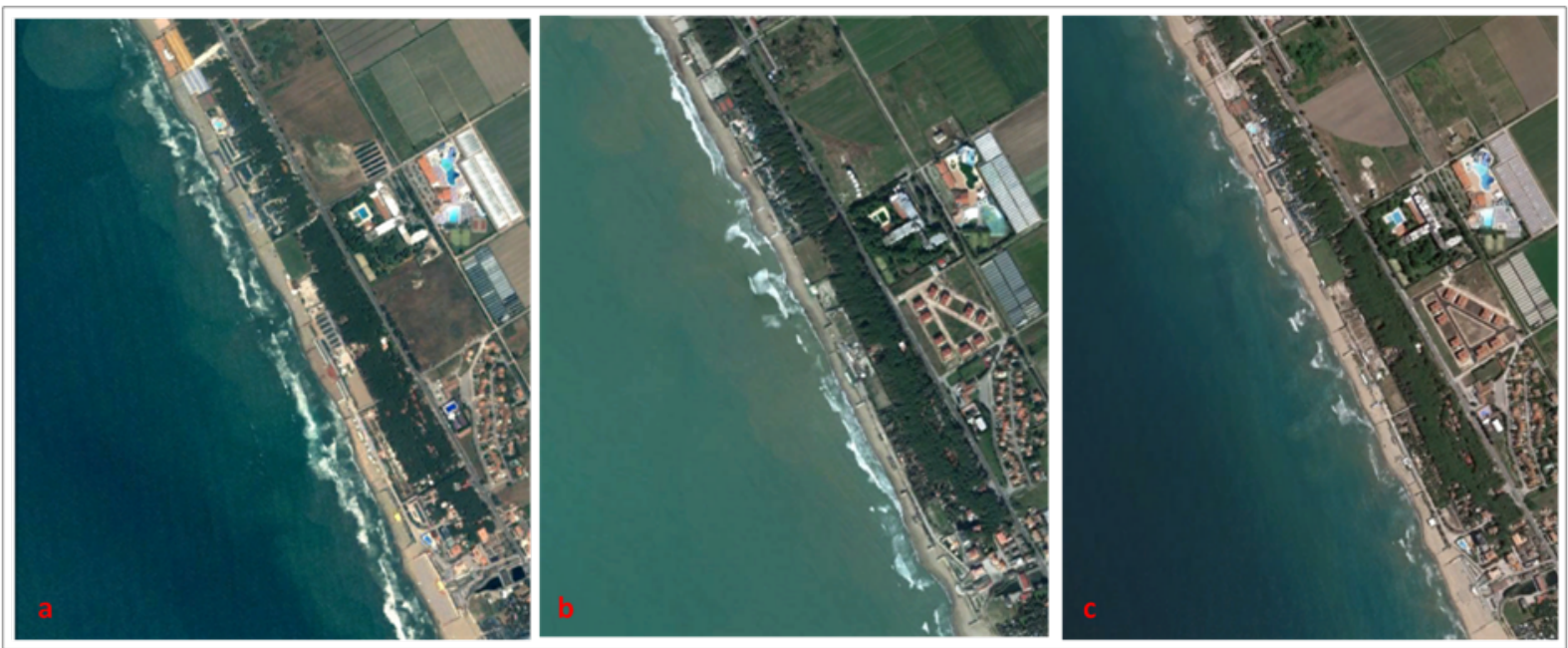

Figure 6. Evidence of rip currents in Google Earth $^{\mathrm{TM}}$ images on (a) 28 June 2007 (image ${ }^{\odot} 2016$ European Space Imaging), (b) 2 May 2013 (image ${ }^{\circledR} 2016$ Digital Globe) and (c) 29 May 2015 (image ${ }^{\circledR}$ Landsat/Copernicus).
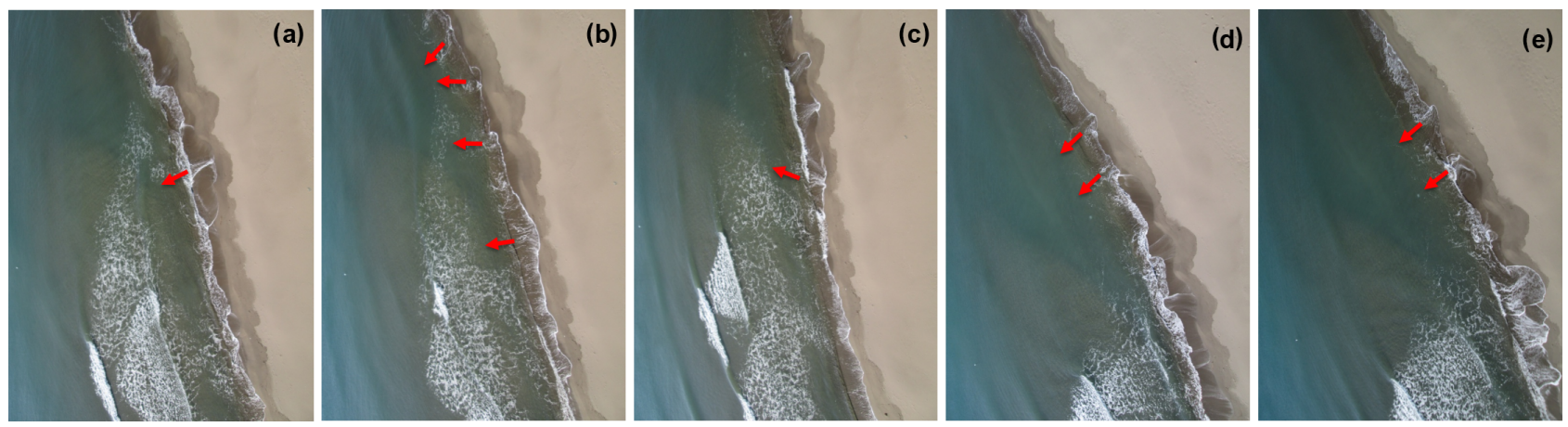

Figure 7. Evidence of rip currents during RPAS acquisition in individual images captured on 21 January 2017. The red arrows are representative of the rip currents.

tion seemed to move, driven by rip currents, towards open sea only within the $-3 /-4 \mathrm{~m}$ depths; then the sediments were shown to rotate and run parallel to the shoreline mainly southeastwards, driven by long-shore currents.

\subsection{Google Earth ${ }^{\mathrm{TM}}$ products and RPAS survey}

The rip current features obtained by the hydrodynamic and sediment calculations were compared with the ones observed by Google Earth $^{\mathrm{TM}}$ (Fig. 6a, b, c) and RPAS images (Fig. 7a, $\mathrm{b}, \mathrm{c}, \mathrm{d}, \mathrm{e})$, corresponding to the sea state characteristics reported in Table 2. The comparison between the simulated and remotely observed sea state evidences that the simulated sea states coming from the west correspond to those observed on 28 June 2007 and 2 May 2013 (Fig. 6a, b), while the ones coming from WSW correspond to the sea states observed on 29 May 2015 (Fig. 6c). Finally, the RPAS-observed rip currents are associated with sea states being characterized by longer swell mixed with sea waves generated by wind direction coming from land. This residual swell coming from
$\mathrm{W}$ and SW is still capable of giving rise to low-defined rip currents, as shown in Fig. 7. These qualitative results are confirmed by the values of the non-dimensional fall velocity $\Omega$ given for each transect and for each observed period of time in the histogram of Fig. 8. The results show clearly that (i) the mean $\Omega$ values are quite different for well-defined rip currents observed cases and low-defined rips cases and (ii) the mean $\Omega$ values associated with 2013 and 2015 sea states (well-defined rip currents) are included in the range reported by Castelle et al. (2010), while the $\Omega$ values associated with the other cases (2007 and 2017) are outside of this range.

\section{Discussion}

The comparison of different profiles and wave numerical simulations in the shallow coastal area of the Sele mouth in the Gulf of Salerno (southern Italy) identified the features of the nearshore circulation, which often produced rip currents. 


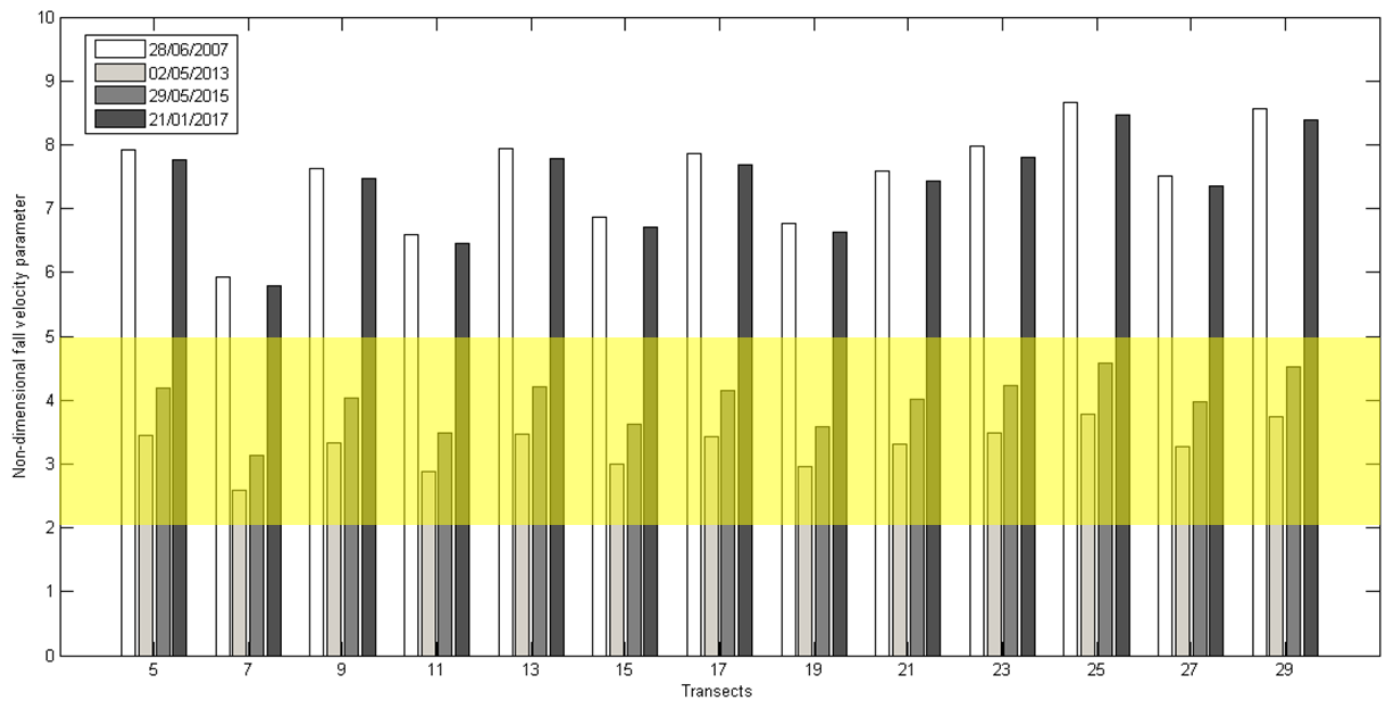

Figure 8. Histogram of the $\Omega$ values of each transect. The yellow strip is the range mostly associated with rip currents (Castelle et al., 2010).

The hydrodynamic inshore simulations clearly identified the cell circulation associated with the shore-normal wave propagation evidenced by the WWIII model. These hydrodynamic results agree with the sediment transport trends, which evidenced that the class of fine sand is brought into suspension in a wide zone of the submerged beach between the -2 and $-7 \mathrm{~m}$ bathymetry, giving rise to rip currents for the first $2-$ $3 \mathrm{~m}$ depth, then being distributed by the long-shore coastal dynamics. The rip spacing of few hundred meters obtained by the bathymetric, sediment and hydrodynamic analysis is in accordance with observations in the range of the dimensionless fall velocity parameter $\Omega=2-5$.

\section{Conclusions}

In this paper the rip current morphodynamics on a microtidal beach addressed by means of hydrodynamic and sediment dynamics modeling was validated by Google Earth ${ }^{\mathrm{TM}}$ and RPAS observations. The wave numerical simulations identified the occurrence of a rip current cell circulation in restricted ranges of heights, periods and incident directions. These hydrodynamic conditions, together with the sediment characteristics, were related with the non-dimensional fall velocity parameter, which proved to be an efficient index for the rip current formation. In fact, the remote observations of well-defined rips performed by Google Earth ${ }^{\mathrm{TM}}$ and RPAS images confirmed the rip current occurrence in a restricted $\Omega$ range. The present results can be used as a basis for a beach hazard forecasting system in order to enhance the swimmers safety. As a matter of fact, the observed channel rips are quite stationary over several days in this long stretch of coastline, giving rise to persistent danger in the surf zone.
Data availability. Salerno wave records are available at www. rilevazioneondametrica.provincia.salerno.it. Numerical simulations are accessible from Parthenope University of Naples (www.meteo. uniparthenope.it/public/data).

Competing interests. The authors declare that they have no conflict of interest.

Special issue statement. This article is part of the special issue "The use of remotely piloted aircraft systems (RPAS) in monitoring applications and management of natural hazards". It is a result of the EGU General Assembly 2016, Vienna, Austria, 17-22 April 2016.

Acknowledgements. The authors are grateful to the CCMMMA (Centro Campano per il Monitoraggio e la Modellistica Marina e Atmosferica), the forecast service of the Parthenope University of Napoli, for the real-time monitoring and forecast of marine, weather and air quality conditions in the Mediterranean area, with a specific focus on the Campania region. The CCMMMA provided the hardware and software resources for the offshore numerical simulations. Additional thanks go to the CUGRI (Inter-University Consortium for the Prediction and Prevention of Major Hazards), to the Civil Protection Department of the Campania Region (which provided the Salerno wave buoy data) and to Dr. Caira for providing the RPAS survey on the coastal area.

Edited by: Francesco Nex

Reviewed by: German Rodriguez and two anonymous referees 


\section{References}

Alberico, I., Amato, V., Aucelli, P., D’argenio, B., Di Paola, G., and Pappone, G.: Historical shoreline change of the Sele Plain (Southern Italy): The 1870-2009 time window, J. Coast. Res., 28, 1638-1647, https://doi.org/10.2112/JCOASTRES-D10-00197.1, 2012.

Amato, V., Aucelli, P., Ciampo, G., Cinque, A., Di Donato, V., Pappone, G., Petrosino, P., Romano, P., Rosskopf, C., and Ermolli, E. R.: Relative sea level changes and paleogeographical evolution of the southern Sele plain (Italy) during the Holocene, Quatern. Int., 288, 112-128, https://doi.org/10.1016/j.quaint.2012.02.003, 2013.

Aucelli, P. P., Amato, V., Budillon, F., Senatore, M. R., Amodio, S., D’Amico, C., Da Prato, S., Ferraro, L., Pappone, G., and Ermolli, E. R.: Evolution of the Sele River coastal plain (southern Italy) during the Late Quaternary by inland and offshore stratigraphical analyses, Rendiconti Lincei, 23, 81-102, https://doi.org/10.1007/s12210-012-0165-5, 2012.

Aucelli, P. P. C., Di Paola, G., Incontri, P., Rizzo, A., Vilardo, G., Benassai, G., Buonocore, B., and Pappone, G.: Coastal inundation risk assessment due to subsidence and sea level rise in a Mediterranean alluvial plain (Volturno coastal plain-southern Italy), Estuarine, Coast. Shelf Sci., in press, 2017.

Bartole, R., Savelli, D., Tramontana, M., and Wezel, F.-C.: Structural and sedimentary features in the Tyrrhenian margin off Campania, Southern Italy, Mar. Geol., 55, 163-180, https://doi.org/10.1016/0025-3227(84)90067-7, 1984.

Benassai, G. and Ascione, I.: Implementation and validation of WaveWatchIII model offshore the coastlines of Southern Italy, in: 25th International Conference on Offshore Mechanics and Arctic Engineering, American Society of Mechanical Engineers, 553560, https://doi.org/10.1115/OMAE2006-92555, 2006.

Benassai, G., Di Paola, G., Aucelli, P., and Maffucci, A.: The response of Sele coastal plain to storm impacts, Rend Online Soc Geol Italy, 21, 474-476, 2012a.

Benassai, G., Migliaccio, M., Montuori, A., and Ricchi, A.: Wave Simulations Through Sar Cosmo-Skymed Wind Retrieval and Verification with Buoy Data, in: The Twenty-second International Offshore and Polar Engineering Conference, International Society of Offshore and Polar Engineers, 2012b.

Benassai, G., Migliaccio, M., and Montuori, A.: Sea wave numerical simulations with COSMO-SkyMed $\odot$ SAR data, J. Coast. Res., 65, 660-665, 2013.

Benassai, G., Di Paola, G., Aucelli, P., Passarella, M., and Mucerino, L.: An inter-comparison of coastal vulnerability assessment methods, in: Engineering Geology for Society and Territory, Springer, 2014.

Benassai, G., Di Paola, G., and Aucelli, P.: Coastal risk assessment of a micro-tidal littoral plain in response to sea level rise, Ocean Coast. Manage., 104, 22-35, https://doi.org/10.1016/j.ocecoaman.2014.11.015, 2015.

Bidlot, J.-R., Holmes, D. J., Wittmann, P. A., Lalbeharry, R., and Chen, H. S.: Intercomparison of the performance of operational ocean wave forecasting systems with buoy data, Weather Forecast., 17, 287-310, 2002.

Bowen, A. J.: Rip currents: 1. Theoretical investigations, J. Geophys. Res., 74, 5467-5478, https://doi.org/10.1029/JC074i023p05467, 1969.
Brander, R., Dominey-Howes, D., Champion, C., Del Vecchio, O., and Brighton, B.: Brief Communication: A new perspective on the Australian rip current hazard, Nat. Hazards Earth Syst. Sci., 13, 1687-1690, https://doi.org/10.5194/nhess-131687-2013, 2013.

Brighton, B., Sherker, S., Brander, R., Thompson, M., and Bradstreet, A.: Rip current related drowning deaths and rescues in Australia 2004-2011, Nat. Hazards Earth Syst. Sci., 13, 10691075, https://doi.org/10.5194/nhess-13-1069-2013, 2013.

Casciello, E., Cesarano, M., and Pappone, G.: Extensional detachment faulting on the Tyrrhenian margin of the southern Apennines contractional belt (Italy), J. Geol. Soc., 163, 617-629, https://doi.org/10.1144/0016-764905-054, 2006.

Casella, E., Rovere, A., Pedroncini, A., Mucerino, L., Casella, M., Cusati, L. A., Vacchi, M., Ferrari, M., and Firpo, M.: Study of wave runup using numerical models and low-altitude aerial photogrammetry: A tool for coastal management, Estuarine, Coast. Shelf Sci., 149, 160-167, 2014.

Castelle, B., Michallet, H., Marieu, V., Leckler, F., Dubardier, B., Lambert, A., Berni, C., Bonneton, P., Barthelemy, E., and Bouchette, F.: Laboratory experiment on rip current circulations over a moveable bed: Drifter measurements, J. Geophys. Res.Ocean., 115, C12008, https://doi.org/10.1029/2010JC006343, 2010.

Dalrymple, R. A.: A mechanism for rip current generation on an open coast, J. Geophys. Res., 80, 3485-3487, 1975.

Dalrymple, R. A. and Lozano, C. J.: Wave-current interaction models for rip currents, J. Geophys. Res.-Ocean., 83, 6063-6071, 1978.

De Pippo, T., Donadio, C., and Pennetta, M.: Morphological control on sediment dispersal along the southern Tyrrhenian coastal zones (Italy), Geol. Rom., 37, 113-121, 2003.

Dean, R. G.: Heuristic models of sand transport in the surf zone, in: First Australian Conference on Coastal Engineering, 1973: Engineering Dynamics of the Coastal Zone, Institution of Engineers, Australia, p. 215, 1973.

Di Lauro, R., Giannone, F., Ambrosio, L., and Montella, R.: Virtualizing general purpose GPUs for high performance cloud computing: an application to a fluid simulator, in: 2012 IEEE 10th International Symposium on Parallel and Distributed Processing with Applications, 863-864, https://doi.org/10.1109/ISPA.2012.136, 2012.

Di Paola, G., Iglesias, J., Rodríguez, G., Benassai, G., Aucelli, P., and Pappone, G.: Estimating coastal vulnerability in a meso-tidal beach by means of quantitative and semi-quantitative methodologies, J. Coast. Res., 61, 303-308, https://doi.org/10.2112/SI61001.30, 2011.

Di Paola, G., Aucelli, P. P., Benassai, G., and Rodríguez, G.: Coastal vulnerability to wave storms of Sele littoral plain (southern Italy), Nat. Hazards, 71, 1795-1819, https://doi.org/10.1007/s11069013-0980-8, 2014.

Drozdzewski, D., Shaw, W., Dominey-Howes, D., Brander, R., Walton, T., Gero, A., Sherker, S., Goff, J., and Edwick, B.: Surveying rip current survivors: preliminary insights into the experiences of being caught in rip currents, Nat. Hazards Earth Syst. Sci., 12, 1201-1211, https://doi.org/10.5194/nhess-12-1201-2012, 2012.

Engle, J.: Formulation of a Rip Current Predictive Index Using Rescue Data, in: 2002 National Conference on Beach Preservation 
Technology, Florida Shore \& Beach Preservation Association, p. $285,2002$.

Folk, R. L. and Ward, W. C.: Brazos River bar: a study in the significance of grain size parameters, J. Sediment. Res., 27, 3-26, 1957.

Gao, S. and Collins, M.: Analysis of grain size trends, for defining sediment transport pathways in marine environments, J. Coast. Res., 10, 70-78, 1994.

Giunta, G., Montella, R., Mariani, P., and Riccio, A.: Modeling and computational issues for air/water quality problems: A grid computing approach, Nuovo Cimento C, 28, 215-224, https://doi.org/10.1393/ncc/i2005-10184-3, 2005.

Holman, R. A., Brodie, K. L., and Spore, N. J.: Surf Zone Characterization Using a Small Quadcopter: Technical Issues and Procedures, IEEE T. Geosci. Remote, 55, 2017-2027, https://doi.org/10.1109/TGRS.2016.2635120, 2017.

Longuet-Higgins, M. S. and Stewart, R.: Radiation stresses in water waves; a physical discussion, with applications, Deep-Sea Res. Oceanogr., Elsevier, 11, 529-562, https://doi.org/10.1016/00117471(64)90001-4, 1964

MacMahan, J., Thornton, E., Stanton, T., and Reniers, A.: RIPEXrip currents on a shore-connected shoal beach, Mar. Geol., 218, 113-134, 2005.

MacMahan, J. H., Thornton, E. B., and Reniers, A. J.: Rip current review, Coast. Engin., 53, 191-208, https://doi.org/10.1016/j.coastaleng.2005.10.009, 2006.

Mangoni, O., Aiello, G., Balbi, S., Barra, D., Bolinesi, F., Donadio, C., Ferrara, L., Guida, M., Parisi, R., Pennetta, M., Trifuoggi, M., and Arienzo, M.: A multidisciplinary approach for the characterization of the coastal marine ecosystems of Monte Di Procida (Campania, Italy), Mar. Pollut. Bull., 112, 443-451, https://doi.org/10.1016/j.marpolbul.2016.07.008, 2016.

Montella, R., Giunta, G., and Riccio, A.: Using grid computing based components in on demand environmental data delivery, in: Proceedings of the second workshop on Use of P2P, GRID and agents for the development of content networks, ACM, 1, 81-86, https://doi.org/10.1145/1272980.1272995, 2007.

Montella, R., Coviello, G., Giunta, G., Laccetti, G., Isaila, F., and Blas, J. G.: A general-purpose virtualization service for HPC on cloud computing: an application to GPUs, in: International Conference on Parallel Processing and Applied Mathematics, Springer, 740-749, https://doi.org/10.1007/978-3-64231464-3_75, 2011.

Nunziata, F., Migliaccio, M., Li, X., and Ding, X.: Coastline extraction using dual-polarimetric COSMO-SkyMed PingPong mode SAR data, IEEE Geosci. Remote S., 11, 104-108, 2014.

Nunziata, F., Buono, A., Migliaccio, M., and Benassai, G.: Dualpolarimetric C-and X-band SAR data for coastline extraction, IEEE J. Sel. Top. Appl., 9, 4921-4928, 2016.

Pappone, G., Alberico, I., Amato, V., Aucelli, P., and Di Paola, G.: Recent evolution and the present-day conditions of the Campanian Coastal plains (South Italy): the case history of the Sele River Coastal plain, WIT Trans. Ecol. Environ., 149, 15-27, https://doi.org/10.2495/CP110021, 2011.

Pappone, G., Aucelli, P. P. C., Aberico, I., Amato, V., Antonioli, F., Cesarano, M., Di Paola, G., and Pelosi, N.: Relative sea-level rise and marine erosion and inundation in the Sele river coastal plain (Southern Italy): scenarios for the next century, Rendiconti
Lincei, 23, 121-129, https://doi.org/10.1007/s12210-012-01664, 2012.

Pennetta, M., Corbelli, V., Esposito, P., Gattullo, V., and Nappi, R.: Environmental Impact of Coastal Dunes in the Area Located to the Left of the Garigliano River Mouth (Campany, Italy), J. Coast. Res., 15, 421-427, https://doi.org/10.2112/SI61-001.52, 2011a.

Pennetta, M., Sica, M., and Abbundo, R.: Canali da rip currents nella spiaggia sommersa presso la foce del Fiume Sele (Golfo di Salerno, Italia), in: Congresso annuale GEOSED, 27-28, https://doi.org/10.3301/ROL.2011.42, 2011b.

Pennetta, M., Brancato, V. M., De Muro, S., Gioia, D., Kalb, C., Stanislao, C., Valente, A., and Donadio, C.: Morphosedimentary features and sediment transport model of the submerged beach of the "Pineta della foce del Garigliano" SCI Site (Caserta, southern Italy), J. Maps, 12, 139-146, https://doi.org/10.1080/17445647.2016.1171804, 2016.

Pham, Q., Malik, T., Foster, I. T., Di Lauro, R., and Montella, R.: SOLE: Linking Research Papers with Science Objects, in: IPAW, Springer, 203-208, https://doi.org/10.1007/978-3-642-34222-6, 2012.

Piscopia, R., Inghilesi, R., Panizzo, A., Corsini, S., and Franco, L.: Analysis of 12-year wave measurements by the Italian Wave Network, in: $28^{\circ}$ ICCE Conference, 121-133, 2002.

Provincia di Salerno: Salerno wave records, www. rilevazioneondametrica.provincia.salerno.it, last access: December 2016.

Roelvink, D., Reniers, A., Van Dongeren, A., de Vries, J. v. T., McCall, R., and Lescinski, J.: Modelling storm impacts on beaches, dunes and barrier islands, Coast. Engin., 56, 11331152, https://doi.org/10.1016/j.coastaleng.2009.08.006, 2009.

Sasaki, T., Horikawa, K., and Hotta, S.: Nearshore current on a gently sloping beach, Coast. Engin., 15, 626-644, 1977.

Shepard, F. and Inman, D.: Nearshore circulation, in: Proc. of First Coastal Engineering Conference, 50-59, 1950.

Short, A. D. and Brander, R. W.: Regional variations in rip density, J. Coast. Res., 813-822, 1999.

Skamarock, W. C., Klemp, J. B., and Dudhia, J.: Prototypes for the WRF (Weather Research and Forecasting) model, in: Preprints, Ninth Conf. Mesoscale Processes, J11-J15, Amer. Meteorol. Soc., Fort Lauderdale, FL, 2001.

Sonu, C. J.: Field observation of nearshore circulation and meandering currents, J. Geophys. Res., 77, 3232-3247, 1972.

Symonds, G. and Ranasinghe, R.: On the formation of rip currents on a plane beach, Coast. Engin., 1, 468-481, 2001.

Tolman, H. L.: User manual and system documentation of WAVEWATCH III TM version 3.14, Technical note, MMAB Contribution, 276, 13-220, 2009.

Turner, I. L., Harley, M. D., and Drummond, C. D.: UAVs for coastal surveying, Coast. Engin., 114, 19-24, 2016.

University of Naples Parthenope, CCMMMA: Numerical simulations, www.meteo.uniparthenope.it/public/data, last access: December 2016.

Zhang, Z., Li, N., Xie, W., Liu, Y., Feng, J., Chen, X., and Liu, L.: Assessment of the ripple effects and spatial heterogeneity of total losses in the capital of China after a great catastrophic shock, Nat. Hazards Earth Syst. Sci., 17, 367-379, https://doi.org/10.5194/nhess-17-367-2017, 2017. 